\title{
Mechanisms Involved in Childhood Obesity-Related Bone Fragility
}

\author{
Maria Felicia Faienza', Gabriele D'Amato ${ }^{2}$, Mariangela Chiarito ${ }^{1}$, Graziana Colaianni ${ }^{3}$, \\ Silvia Colucci ${ }^{4}$, Maria Grano ${ }^{3}$, Filomena Corbo ${ }^{5}$ and Giacomina Brunetti ${ }^{4 *}$ \\ ${ }^{1}$ Department of Biomedical Sciences and Human Oncology, University of Bari Aldo Moro, Bari, Italy, ${ }^{2}$ Neonatal Intensive \\ Care Unit, Di Venere Hospital, Bari, Italy, ${ }^{3}$ Department of Emergency and Organ Transplantation, Section of Human Anatomy \\ and Histology, University of Bari, Bari, Italy, ${ }^{4}$ Department of Basic and Medical Sciences, Neurosciences and Sense Organs, \\ Section of Human Anatomy and Histology, University of Bari Aldo Moro, Bari, Italy, ${ }^{5}$ Department of Pharmacy-Drug Science, \\ University of Bari Aldo Moro, Bari, Italy
}

OPEN ACCESS

Edited by:

Guillaume Mabilleau,

Université d'Angers, France

Reviewed by:

Tetsuya Izawa,

Doshisha University, Japan

Basem M. Abdallah,

University of Southern Denmark,

Denmark

*Correspondence:

Giacomina Brunetti

giacomina.brunetti@uniba.it

Specialty section:

This article was submitted to

Bone Research,

a section of the journal

Frontiers in Endocrinology

Received: 02 January 2019

Accepted: 11 April 2019

Published: 03 May 2019

Citation:

Faienza MF, D'Amato $G$, Chiarito $M$, Colaianni G, Colucci S, Grano M,

Corbo F and Brunetti G (2019)

Mechanisms Involved in Childhood

Obesity-Related Bone Fragility.

Front. Endocrinol. 10:269.

doi: 10.3389/fendo.2019.00269
Childhood obesity is one of the major health problems in western countries. The excessive accumulation of adipose tissue causes inflammation, oxidative stress, apoptosis, and mitochondrial dysfunctions. Thus, obesity leads to the development of severe co-morbidities including type 2 diabetes mellitus, liver steatosis, cardiovascular, and neurodegenerative diseases which can develop early in life. Furthermore, obese children have low bone mineral density and a greater risk of osteoporosis and fractures. The knowledge about the interplay bone tissue and between adipose is still growing, although recent findings suggest that adipose tissue activity on bone can be fat-depot specific. Obesity is associated to a low-grade inflammation that alters the expression of adiponectin, leptin, IL-6, Monocyte Chemotactic Protein 1 (MCP1), TRAIL, LIGHT/TNFSF14, OPG, and TNF $\alpha$. These molecules can affect bone metabolism, thus resulting in osteoporosis. The purpose of this review was to deepen the cellular mechanisms by which obesity may facilitate osteoporosis and bone fractures.

Keywords: osteoporosis, low grade inflammation, osteoimmunology, osteoclast, cytokines

\section{INTRODUCTION}

Childhood obesity represents an international public health problem with epidemic proportions (1). The World Obesity Federation showed a strong increase of childhood overweight and obesity in several low-, middle-, and high-income regions over the past three decades (2). In the USA $\sim 17 \%$ of children and adolescents are obese, representing a risk for health status in adulthood and life expectancy $(3,4)$.

The excess of adipose tissue causes inflammation, oxidative stress, apoptosis and mitochondrial dysfunctions $(5,6)$. Therefore, obesity can lead to the onset of type-2-diabetes, liver steatosis, cardiovascular and neurodegenerative diseases which can develop early in life (7-12). Different studies have shown a susceptibility to skeletal fractures in obese children (13-23), suggesting that adipose tissue affects bone metabolism $(24,25)$. Therefore, the excess of fat could reduce the peak of bone mass reached during childhood and adolescence, with a potential osteoporotic risk in adulthood $(1,26)$. The bone fragility in obese population is due to an increase in fall injury risk, an unbalanced diet and a low physical activity. Despite the knowledge about the interplay between bone and adipose tissue is still growing, recent findings suggest that the influence of adipose tissue on bone can be fat-depot specific. In fact, the visceral fat storage may determine negative consequences on bone, while normal fat depots seem to affect positively the skeleton (27). 
Furthermore, obesity can act in a different way on specific skeletal compartments (i.e., trabecular vs. cortical) and sites (i.e., weight-bearing vs. non-weight-bearing) (28). The aim of our review was to overview the cellular mechanisms by which obesity regulates bone remodeling leading to osteoporosis and fracture risk (Figure 1).

\section{MESENCHYMAL STEM CELL FATE}

The link between obesity and osteoporosis can be explained by the common stem cell precursor shared by osteoblasts and adipocytes (29). Two groups of crucial factors, CEBP- $\alpha,-\beta,-\delta$, and PPAR $-\alpha,-\gamma 2$ and $-\delta$, need to be activated to attain a complete adipocytic differentiation of a mesenchymal stem cell. Otherwise, activation of other crucial factors (i.e., RUNX2, BMP2, TGF$\beta$, and Osterix) are required to shift the differentiation of a mesenchymal cell into osteoblast (29). The differentiation "switches" characterizing stem cell fate are strictly linked to the stimuli present in the microenvironment. Furthermore, adipocytes cultured from marrow display the capability to revert to a proliferative status and thus differentiate in osteoblasts (30).

\section{OBESITY AND BONE TURNOVER}

The link between obesity and bone turnover has been evaluated both in humans and murine models, and the excess of fat mass is associated with reduced bone mineral density (BMD) (31-34). Obesity influences bone metabolism by different mechanisms. It stimulates pre-osteoblasts to differentiate toward adipocytes rather than osteoblasts, thus filling the cavities of bone marrow with adipocytes rather than trabecular bone with consequent bone fragility increase (35). Consistently, in obese adolescents and young adults, total and trabecular BMD and trabecular number have been inversely related with marrow adipose tissue (MAT) at the distal tibia, but not with lumbar spine MAT (36). Obesity can also enhance bone resorption by the increase of pro-inflammatory cytokine levels [Tumor Necrosis factor alpha (TNF $\alpha$ ) and interleukin-6 (IL-6)], which promote osteoclast formation and activity by affecting RANKL/RANK/OPG pathway $(37,38)$. Bone marrow fat also may regulate osteoclastogenesis by producing RANKL (39). Obese subjects show low serum levels of adiponectin (40), an adipokine that inhibits osteoclast formation and activity (41). High leptin levels associated with reduced adiponectin may stimulate both macrophage accumulation into the adipose tissue (42) and adhesion of macrophages to endothelial cells (43). Several studies have demonstrated the impact of obesity on bone remodeling. Weiler et al. found that body fat percentage is correlated with suboptimal achievement of peak of bone mass in a cross-sectional study involving 60 girls (10-19 years old) (44). Goulding et al. showed that severe obesity is associated with higher risk of distal forearm fractures in boys aged 3-19 years (16).

Furthermore, Hsu et al. reported an increased risk for osteoporosis and non-spine fractures related with high percentage of body fat in a cross-sectional study involving 7,137 men, 2,248 postmenopausal women and 4,585 premenopausal women aged 25-64 years old (33). In leptin-deficient (ob/ob) obese mice, a reduction of femoral $\mathrm{BMD}$, trabecular bone volume, and cortical thickness has been observed (45). Using a mouse model of diet-induced obesity, it has been found that mice fed with a high fat diet (HFD) had cancellous bone loss in the proximal tibia, together with a significant body weight increase (46). In the models, an increase of leptin and TRAP serum levels, a high RANKL/OPG ratio in cultured osteoblasts, and in the number of osteoclasts was observed (46-48). HFD determines an augment of bone marrow adiposity together with a reduction of $\mathrm{BMD}$ in several bone segments, and an increase of IL-6, TNF $\alpha$, peroxisome proliferator-activated receptor $\gamma$ (PPAR $\gamma$ ) (49). Additionally, HFD decreases intestinal absorption of calcium, through the production of unabsorbable calcium soaps by free fatty acids (50-52).

\section{HIGH LEVELS OF PRO-INFLAMMATORY CYTOKINES IN OBESITY}

Obesity is characterized by a low-grade chronic inflammation. The discovery of high $\mathrm{TNF} \alpha$ levels in the adipose tissue of obese mice offered the initial demonstration of a crosstalk between obesity and inflammation (27). Furthermore, the detection of leptin, hormone produced by adipocytes, further sustained the idea that adipose tissue is not only an energy storage but it is also a dynamic endocrine organ $(53,54)$. In fact, the chronic inflammatory status associated to obesity is characterized by abnormal cytokine production, and activation of signaling pathways of inflammation, with consequent development of obesity-related diseases (55). Adipose tissue is rich of macrophages, key source of inflammatory cytokines (56, 57). Obese subjects produce higher amounts of TNF $\alpha$ and proinflammatory cytokines (IL-6 and C-reactive protein) in adipose tissue than lean controls (58-60). Furthermore, the levels of adiponectin are lower in obese patients respect to controls (40). Obesity has also been related with inflammatory musculoskeletal diseases (i.e., osteoarthritis) (61). The low-grade inflammation which characterizes obesity may also influence endochondral longitudinal bone growth together with change in nutrients, minerals, and hormone metabolism (62). In obesity, the altered levels of numerous molecules inhibit osteoblastogenesis, as $\mathrm{TNF} \alpha, \mathrm{DKK} 1$, sclerostin, IL-6, serotonin, and advanced glycation end products (AGEs) [revised in Roy et al. (63)]. Interestingly, many pro-inflammatory cytokines involved in obesity are also crucial players of osteoclast formation and activation, and are known to be involved in bone disease (64-66), suggesting a link between obesity and bone turnover. In particular, in this review we focused the attention on MCP1, TRAIL, LIGHT, OPG, and $\mathrm{TNF} \alpha$ (Figure 2).

\section{MCP1}

The chemokine Monocyte Chemotactic Protein-1 (MCP1) interacts with the receptor CCR2, its expression is ubiquitous and it is up-regulated by numerous stimuli. Firstly, MCP1 has 


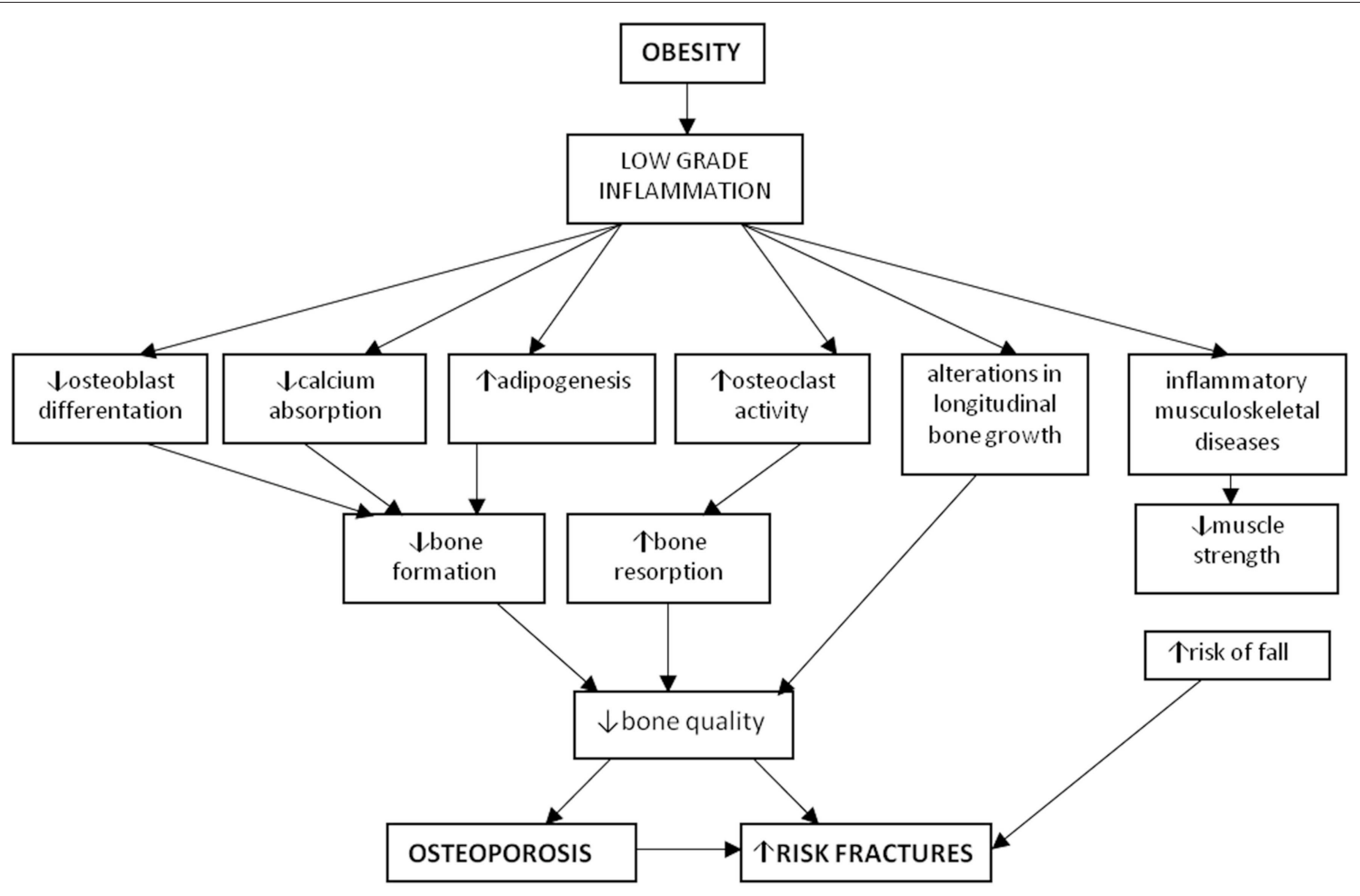

FIGURE 1 | Osteoporosis and obesity. Obesity is characterized by a low-grade chronic inflammation leading to increased osteoclastogenesis and adipogenesis, together with decreased osteoblastogenesis and muscle strength thus determining osteoporosis and increased risk of fractures.

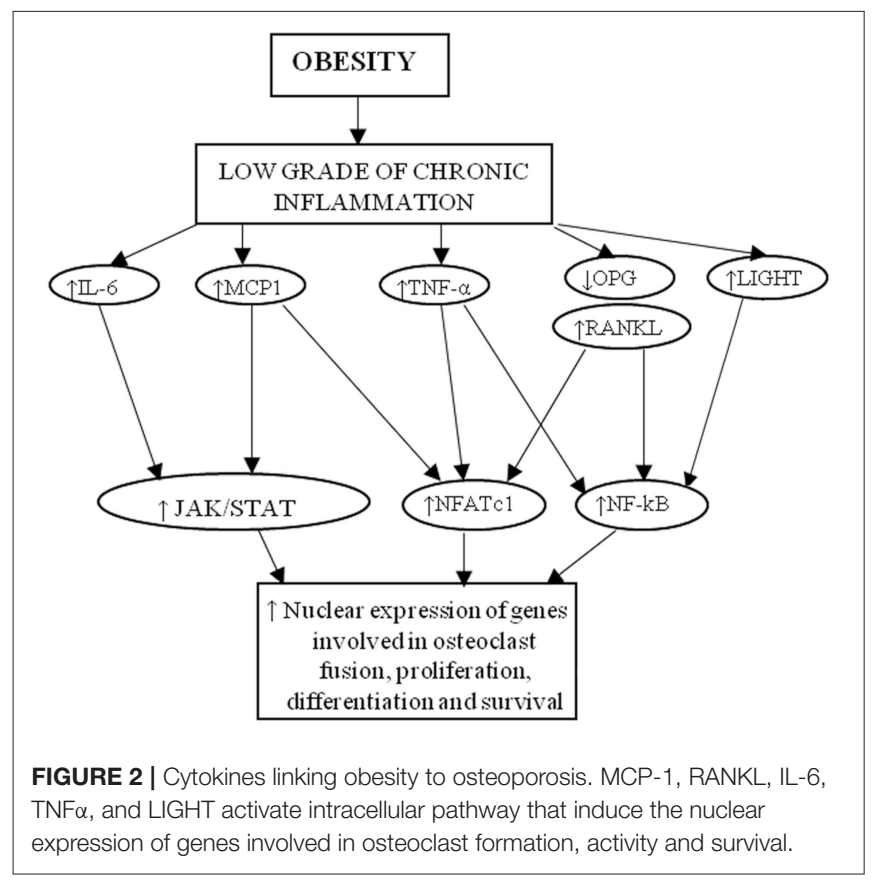

been purified from myelomonocytic cell line THP-1 (67), but it is expressed by numerous normal cells, such as endothelial cells (68-72), fibroblasts $(73,74)$, mononuclear cells $(73,75-82)$, mast cells (83), epithelial cells (84), keratinocytes (85), melanocytes
(86), smooth muscle cells $(68,87,88)$, mesothelial cells (89), adipocytes $(90,91)$, mesangial cells (92-96), chondrocytes (97), osteoblasts, astrocytes $(98,99)$, and microglia (99). In untreated normal cells, MCP1 levels are low, while tumor cell lines produce MCP1 constitutively $(67,100-104)$. The expression of MCP1 can also be downregulated by glucocorticoids (e.g., dexamethasone), cytokines (e.g., IL-13), and nitric oxide (79, $80,97,105-109)$. The expression of MCP1 and its receptor is higher in subcutaneous and visceral adipose tissues of obese patients than controls (90). Additionally, in omental fat of subjects with severe obesity, an increase of MCP1 expression together with an elevated macrophage infiltration was found (91). MCP1 levels are higher in obese adults (110) and children (111) compared to aged-matched controls. In obese patients MCP1 levels were augmented by fructose expenditure (112), reduced by low-glycemic index diet (113), and modulated by PTH (114). Moreover, $1 \alpha$-25-dihydroxy-vitamin D decreases MCP1 production by adipocytes (115). CCR2-deficient mice fed with a HFD showed insulin resistance and reduced accumulation of visceral fat (78). Furthermore, MCP1 exerts a pro-angiogenic action (116), thus contributing to the expansion of adipose tissues.

MCP1 interaction with CCR2 on monocytes/macrophages leads to osteoclastogenesis via JAK/STAT and Ras/MAPK signaling pathways. However, RANKL co-treatment is mandatory to generate active bone resorptive osteoclasts (117). 


\section{TRAIL}

TRAIL is a TNF superfamily member, initially known for its selective pro-apoptotic activity on cancer cell death (118). In humans, TRAIL binds to its death domain (DD)containing receptors, DR5 and DR4, as well as decoy receptors osteoprotegerin (OPG), DcR1 and DcR2. In contrast to humans, mice express only one death receptor, mDR5, showing about $60 \%$ sequence homology to human DR4 and DR5 (118), and as decoy receptors, $\mathrm{mDcR} 1, \mathrm{mDcR} 2$ and OPG. TRAIL also affects non-cancer cell viability and activity, such as thymocytes (119), neural cells (120), hepatocytes (121), osteoclasts (122, 123), stem cells (124), valvular interstitial cells $(125,126)$, vascular smooth muscle cells (127), and osteoblasts (128-130). TRAIL pro-apoptotic signal in undifferentiated osteoblasts determines the activation of caspases (131). In lymphomonocyte cultures from donors TRAIL directly induces osteoclastogenesis in the absence of RANKL, whereas generates an inhibitory action when used simultaneously to RANKL (132). This last condition is associated with the inhibition of the phosphorylation of P38/MAPK (133). TRAIL controls homeostasis of the immune system in health and disease. Zoller et al. demonstrated that TRAIL determines an inflammatory status in pre-adipocytes and adipocytes (134). Funcke et al. reported that TRAIL induces the proliferation of human pre-adipocyte via ERK1/2 activation (135). Consistently, TRAIL takes part in the pathogenesis of metabolic diseases, i.e., obesity $(121,136)$. It has been demonstrated a positive association between TRAIL serum levels and body fat, serum lipid concentrations (137), waistcircumference and fat mass in healthy subjects (138). TRAIL serum levels were also positively correlated with higher energy balance (139), LDL and waist circumference, supporting a significant link between visceral adiposity and TRAIL (140). Even if these reports demonstrated high TRAIL levels in obesity, other authors failed to show such correlation $(125,138,141,142)$. Furthermore, a positive correlation between weight gain and TRAIL has been demonstrated in obese animal models. In detail, in adipose tissues of leptin-deficient mice the expression of TRAIL was significantly higher respect to wild-type mice (125). Furthermore, TRAIL levels decreased following an overnight fasting, and then rescued following feeding (125). Otherwise, results derived from TRAIL-treated wild-type and HFD fed, or TRAIL-deficient mice, support a defensive role for TRAIL in obesity. Bernardi et al. reported that in mice fed with a HFD, weekly injections of TRAIL generated a smaller fat mass compared to controls. TRAIL-mediated weight loss was linked to decreased transcript levels of TNF $\alpha$, caspase-3, MCP1, augmented apoptosis in adipocytes, and decreased IL-6 serum levels (143). Consistently, TRAIL ${ }^{-/-} \mathrm{ApoE}^{-/-}$mice fed with HFD showed high levels of IL-6 and MCP1, together with adipocyte hypertrophy and weight gain respect to $\mathrm{ApoE}^{-/-}$mice (144). Although Di Bartolo et al. (144) and Bernardi et al. (143) suggest that TRAIL may be beneficial to treat obesity, conversely Keuper et al. (125) found that TRAIL stimulated in vitro insulin resistance in adipocytes. Thus, considering the effect of TRAIL on adipose tissue together with its pro-osteoclastogenic and osteoblastic pro-apoptotic effects, further studies are needed to elucidate the role of TRAIL in obesity and related bone disease, overall in childhood.

\section{LIGHT/TNFSF14}

LIGHT (homologous to Lymphotoxins exhibiting Inducible expression and competing with herpes simplex virus Glycoprotein D for herpes virus entry mediator [HVEM], a receptor expressed by T-lymphocytes) is part of TNF superfamily (TNFSF14) and a crucial cytokine of the TNF-lymphotoxin network (145-148). It is expressed by natural-killer cells, activated T-cells, granulocytes, monocytes, and immature dendritic cells (149-151). LIGHT can bind two receptors, lymphotoxin-beta receptor (LT $\beta R$ ) and Herpes virus entry mediator (HVEM). LT $\beta$ R is present on stromal and myeloid cells (146), HVEM on hematopoietic, epithelial and endothelial cells $(151,152)$. LIGHT-HVEM interaction determines a potent T-cell co-stimulatory effect (153-156). LIGHT-deficient mice showed an impaired activity of CD8+ T-cells and reduced trabecular bone (157-159). LIGHT has a pro-osteoclastogenic effect and we demonstrated that its high levels are linked to bone-disease patients (160-163). LIGHT triggers osteoclastogenesis through the phosphorylation of Akt, nuclear factor- $\kappa \mathrm{B}(\mathrm{NF} \kappa \mathrm{B})$ and JNK pathways, it indirectly also inhibits osteoblastogenesis through immune cells (160). Moreover, LIGHT is involved in adipogenesis $(164,165)$. In detail, Tiller et al. reported that LIGHT inhibits adipose differentiation without affecting adipocyte metabolism (166). Otherwise, Kim et al. demonstrated that LIGHT has a key role in adipose tissue inflammatory responses through the increase of macrophages/T-cell infiltration and the release of inflammatory cytokines. In this system LIGHT effect is HVEM-mediated (164). HVEM deficiency displays a protective role against adipose tissue inflammation induced by ovariectomy (165). It has been reported that LIGHT signaling attenuates beige fat biogenesis (167). Human studies demonstrated high LIGHT levels in obese adults compared to controls (168). Interestingly, our preliminary results showed high LIGHT levels in obese children (169).

\section{OPG/RANKL}

Osteoprotegerin (OPG), soluble receptor for TRAIL and RANKL, is part of the TNF receptor superfamily. OPG, primarily known as bone resorption inhibitor, shows also antiapoptotic and anti-inflammatory effects (170). OPG role has been evaluated in metabolic diseases (171). Indeed, low levels of OPG have been found in non-alcoholic fatty liver disease (NAFLD), important consequence of obesity $(172,173)$. Erol et al. found that obese children showed significantly lower OPG levels compared to the controls. A reduction of OPG levels in obese subjects has been described in some studies $(174,175)$, otherwise no relationship has been found between BMI and OPG in other reports $(176,177)$. Interestingly, UgurAltan et al. (174) found that the lowest OPG levels are associated with the highest HOMA-IR values, and serum OPG levels negatively correlated with fasting insulin, HOMA-IR, 
and glucose. Otherwise, Suliburska et al. (178) showed that obese adolescents displayed higher OPG levels compared to controls, that positively correlated with insulin resistance. Studies on adults reported a potential correlation between metabolic syndrome, insulin resistance, NAFLD, and OPG levels (172181). These studies demonstrated that in NAFLD the levels of OPG in sera could be utilized as a non-invasive liver damage indicator (174).

Obesity is also associated with increased secretion of RANKL by osteoblasts as well as elevated levels of the RANKL/OPG ratio (182). RANKL-RANK interaction leads to the activation of the transcription factors NFKB and AP-1, which in turn activates nuclear factor of activated T-cells, cytoplasmic 1 (NFATc1). The latter translocates into the nucleus, thus inducing the expression of genes involved in osteoclast formation and activity.

\section{TNF $\alpha$}

$\mathrm{TNF} \alpha$ is a pro-inflammatory molecule involved in the regulation of inflammatory response, cell differentiation, proliferation, and apoptosis (183). TNF $\alpha$ binds two receptors, type 1 or 2, and activates $\mathrm{NFkB}$ and MAPK signaling (184), and is produced mainly by stromal-vascular cells and adipose tissue macrophages (185). TNF $\alpha$ is an inhibitor of osteoblastogenesis (186), adipogenesis and adipocyte differentiation, mainly by binding TNFR1 and activating the NFKB, ERK1/2 and JNK pathways (187). Another mechanism by which TNF $\alpha$ inhibits adipogenesis is the activation of $\mathrm{Wnt} / \beta$-catenin pathway and inhibition of transcription factors, such as PPAR $\gamma$ and C/EBPs $(188,189)$. High levels of TNF $\alpha$ have been found in obese and diabetic subjects (58). The TNF $\alpha$ treatment in 3T3-L1 cells and rats induces insulin resistance (190), whereas the suppression of $\mathrm{TNF} \alpha$ and receptor genes improves insulin sensitivity in ob/ob rodent model (191). Moreover, TNF $\alpha$ upregulates miR-155 and miR-27 by activating the NFKB pathway, thus inhibiting early adipogenic transcription factors, i.e., C/EBP $\beta$ and CREB (192,

\section{REFERENCES}

1. Wang Y, Lobstein T. Worldwide trends in childhood overweight and obesity. Int J Pediatr Obes. (2006) 1:11-25. doi: 10.1080/174771606005 86747

2. Lobstein T, Jackson-Leach R, Moodie ML, Hall KD, Gortmaker SL, Swinburn BA, et al. Child and adolescent obesity: part of a bigger picture. Lancet. (2015) 385:2510-20. doi: 10.1016/S0140-6736(14)61746-3

3. Ogden CL, Carroll MD, Lawman HG, Fryar CD, Kruszon-Moran D, Kit $\mathrm{BK}$, et al. Trends in obesity prevalence among children and adolescents in the United States, 1988-1994 Through 2013-2014. J Am Med Assoc. (2016) 315:2292-9. doi: 10.1001/jama.2016.6361

4. Styne DM, Arslanian SA, Connor EL, Farooqi IS, Murad MH, Silverstein JH, et al. Pediatric obesity-assessment, treatment, and prevention: an endocrine society clinical practice guideline. J Clin Endocrinol Metab. (2017) 102:70957. doi: 10.1210/jc.2016-2573

5. Faienza MF, Acquafredda A, Tesse R, Luce V, Ventura A, Maggialetti $\mathrm{N}$, et al. Oxidative stress in obesity and metabolic syndrome in children and adolescents. Horm Res Paediatr. (2012) 78:158-64. doi: 10.1159/000 342642
193). TNF $\alpha$ also down-regulates miR-103 and miR-143, which accelerate adipogenesis (194).

$\mathrm{TNF} \alpha$ shows a pro-osteoclastogenic effect that can be direct or indirect. In detail, for the direct mechanism $\mathrm{TNF} \alpha$ binds to TNFR1 through NF- $\mathrm{B}$, JNK and p38 with consequent activation of NFATc1, which promotes the transcription of genes involved in osteoclast formation and activity. Moreover, TNF $\alpha$ indirectly affects osteoclast formation by promoting RANKL expression in bone marrow stromal cells (195). Otherwise, TNF $\alpha$ promoted osteoclastogenesis only in the presence of RANKL permissive levels (196).

\section{CONCLUSIONS}

Although childhood obesity has not been yet identified as a direct cause of osteoporosis, several cellular mechanisms linked to the accumulation of fat in the body can contribute to osteoporosis and bone fractures. Low grade chronic inflammation commonly exists in obese populations and the cytokines negatively affect bone health. Obesity positively regulates osteoclasts functioning by up-regulating the production of RANKL, LIGHT, TRAIL, TNF $\alpha$, MCP1 and inhibiting osteoblastogenesis, thereby accelerating bone resorption. Future investigations on the relationship between cytokines and adipogenesis are expected to lead to the improvement of management strategies for osteoporosis associated to obesity.

\section{AUTHOR CONTRIBUTIONS}

MF and GB write the review. FC, MG, and SC critically revised the paper. GC, GD, and MC performed the bibliographic research and realized the figures. All the authors critically revised the paper.

\section{ACKNOWLEDGMENTS}

The authors thank FFARB for providing funding to GB.

6. Giordano P, Del Vecchio GC, Cecinati V, Delvecchio M, Altomare M, De Palma F, et al. Metabolic, inflammatory, endothelial and haemostatic markers in a group of Italian obese children and adolescents. Eur J Pediatr. (2011) 170:845-50. doi: 10.1007/s00431-010-1356-7

7. Ciccone MM, Faienza MF, Altomare M, Nacci C, Montagnani M, Valente F, et al. Endothelial and metabolic function interactions in overweight/obese children. J Atheroscler Thromb. (2016) 23:950-9. doi: 10.5551/jat.31740

8. Nacci C, Leo V, De Benedictis L, Carratù MR, Bartolomeo N, Altomare $\mathrm{M}$, et al. Elevated endothelin-1 (ET-1) levels may contribute to hypoadiponectinemia in childhood obesity. J Clin Endocrinol Metab. (2013) 98:E683-693. doi: 10.1210/jc.2012-4119

9. Faienza MF, Acquafredda A, Tesse R, Luce V, Ventura A, Maggialetti N, et al. Risk factors for subclinical atherosclerosis in diabetic and obese children. Int J Med Sci. (2013) 10:338-43. doi: 10.7150/ijms.5181

10. Faienza MF, Santoro N, Lauciello R, Calabrò R, Giordani L, Di Salvo G, et al. IGF2 gene variants and risk of hypertension in obese children and adolescents. Pediatr. Res. (2010) 67:340-344. doi: 10.1203/PDR.0b013e3181d22757

11. Marzano F, Faienza MF, Caratozzolo MF, Brunetti G, Chiara M, Horner DS, et al. Pilot study on circulating miRNA signature in children with obesity 
born small for gestational age and appropriate for gestational age. Pediatr Obes. (2018) 13:803-11. doi: 10.1111/ijpo.12439

12. Faienza MF, Wang DQ, Frühbeck G, Garruti G, Portincasa P. The dangerous link between childhood and adulthood predictors of obesity and metabolic syndrome. Intern Emerg Med. (2016) 11:175-82. doi: 10.1007/s11739-015-1382-6

13. Goulding A, Cannan R, Williams SM, Gold EJ, Taylor RW, Lewis-Barned NJ. Bone mineral density in girls with forearm fractures. J Bone Miner Res. (1998) 13:143-8. doi: 10.1359/jbmr.1998.13.1.143

14. Goulding A, Jones L, Taylor RW, Manning PJ, Williams SM. More broken bones: a 4-year double cohort study of young girls with and without distal forearm fractures. J Bone Miner Res. (2000) 15:2011-8. doi: 10.1359/jbmr.2000.15.10.2011

15. Skaggs DL, Loro ML, Pitukcheewanont P, Tolo V, Gilsanz V. Increased body weight and decreased radial cross-sectional dimensions in girls with forearm fractures. J Bone Miner Res. (2001) 16:1337-42. doi: 10.1359/jbmr.2001.16.7.1337

16. Goulding A, Jones IE, Taylor RW, Williams SM, Manning PJ. Bone mineral density and body composition in boys with distal forearm fractures: a dual-energy x-ray absorptiometry study. J Pediatr. (2001) 139:509-15. doi: $10.1067 / \mathrm{mpd} .2001 .116297$

17. Davidson PL, Goulding A, Chalmers DJ. Biomechanical analysis of arm fracture in obese boys. J Paediatr Child Health. (2003) 39:657-64. doi: 10.1046/j.1440-1754.2003.00243.x

18. Goulding A, Grant AM, Williams SM. Bone and body composition of children and adolescents with repeated forearm fractures. J Bone Miner Res. (2005) 20:2090-6. doi: 10.1359/JBMR.050820

19. Taylor ED, Theim KR, Mirch MC, Ghorbani S, Tanofsky-Kraff M, AdlerWailes DC, et al. Orthopedic complications of overweight in children and adolescents. Pediatrics. (2006) 117:2167-74. doi: 10.1542/peds.2005-1832

20. Dimitri P, Wales JK, Bishop N. Fat and bone in children: differential effects of obesity on bone size and mass according to fracture history. J Bone Miner Res. (2010) 25:527-36. doi: 10.1359/jbmr.090823

21. Kessler J, Koebnick C, Smith N, Adams A. Childhood obesity is associated with increased risk of most lower extremity fractures. Clin Orthop Relat Res. (2013) 471:1199-207. doi: 10.1007/s11999-012-2621-z

22. Fornari ED, Suszter M, Roocroft J, Bastrom T, Edmonds EW, Schlechter J. Childhood obesity as a risk factor for lateral condyle fractures over supracondylar humerus fractures. Clin Orthop Relat Res. (2013) 471:1193-8. doi: 10.1007/s1 1999-012-2566-2

23. Sabhaney V, Boutis K, Yang G, Barra L, Tripathi R, Tran TT, et al. Bone fractures in children: is there an association with obesity? J Pediatr. (2014) 165:313-8. doi: 10.1016/j.jpeds.2014.04.006

24. Rosen CJ, Klibanski A. Bone, fat, and body composition: evolving concepts in the pathogenesis of osteoporosis. Am J Med. (2009) 122:409-14. doi: 10.1016/j.amjmed.2008.11.027

25. Kawai M, de Paula FJ, Rosen CJ. New insights into osteoporosis: the bone-fat connection. J Intern Med. (2012) 272:317-29. doi: 10.1111/j.1365-2796.2012.02564.x

26. Matkovic V, Jelic T, Wardlaw GM, Iliac JZ, Goes PK, Wright JK, et al. Timing of peak bone mass in Caucasian females and its implication for the prevention of osteoporosis Inference from a cross-sectional model. J Clin Invest. (1994) 93:799-808.

27. Hotamisligil GS, Shargill NS, Spiegelman BM. Adipose expression of tumor necrosis factor-alpha: direct role in obesity-linked insulin resistance. Science. (1993) 259:87-91. doi: 10.1126/science.7678183

28. Farr JN, Dimitri P. The impact of fat and obesity on bone microarchitecture and strength in children. Calcif Tissue Int. (2017) 100:500-13. doi: 10.1007/s00223-016-0218-3

29. Rosen CJ, Bouxsein ML. Mechanisms of disease: is osteoporosis the obesity of bone? Nat Clin Pract Rheumatol. (2006) 2:35-43. doi: 10.1038/ncprheum0070

30. Bennett JH, Joyner CJ, Triffitt JT, Owen ME. Adipocytic cells cultured from marrow have osteogenic potential. J. Cell. Sci. (1991) 99 (Pt 1):131-139.

31. Goulding A, Taylor RW, Jones IE, McAuley KA, Manning PJ, Williams SM. Overweight and obese children have low bone mass and area for their weight. Int J Obes Relat Metab Disord. (2000) 24:627-32. doi: 10.1038/sj.ijo.08 01207
32. Blum M, Harris SS, Must A, Naumova EN, Phillips SM, Rand WM, et al. Leptin, body composition and bone mineral density in premenopausal women. Calcif Tissue Int. (2003) 73:27-32. doi: 10.1007/s00223-0021019-4

33. Hsu YH, Venners SA, Terwedow HA, Feng Y, Niu T, Li Z, et al. Relation of body composition, fat mass, and serum lipids to osteoporotic fractures and bone mineral density in Chinese men and women. Am J Clin Nutr. (2006) 8:146-54. doi: 10.1093/ajcn/83.1.146

34. Pollock NK, Laing EM, Baile CA, Hamrick MW, Hall DB, Lewis RD. Is adiposity advantageous for bone strength? A peripheral quantitative computed tomography study in late adolescent females. Am J Clin Nutr. (2007) 86:1530-8. doi: 10.1093/ajcn/86.5.1530

35. Cao JJ. Effects of obesity on bone metabolism. J Orthop Surg Res. (2011) 6:30. doi: 10.1186/1749-799X-6-30

36. Singhal V, Torre Flores LP, Stanford FC, Toth AT, Carmine B, Misra $M$, et al. Differential associations between appendicular and axial marrow adipose tissue with bone microarchitecture in adolescents and young adults with obesity. Bone. (2018) 116:203-6. doi: 10.1016/j.bone.2018. 08.009

37. Pfeilschifter J, Koditz R, Pfohl M, Schatz H. Changes in proinflammatory cytokine activity after menopause. Endocr Rev. (2002) 23:90-119. doi: 10.1210/er.23.1.90

38. Khosla S. Minireview: the OPG/RANKL/RANK system. Endocrinology. (2001) 142:5050-5. doi: 10.1210/en.142.12.5050

39. Naveiras O, Nardi V, Wenzel PL, Hauschka PV, Fahey F, Daley GQ, et al. Bone-marrow adipocytes as negative regulators of the haematopoietic microenvironment. Nature. (2009) 460:259-63. doi: 10.1038/nature08099

40. Arita Y, Kihara S, Ouchi N, Takahashi M, Maeda K, Miyagawa J, et al. Paradoxical decrease of an adipose-specific protein, adiponectin, in obesity. Biochem Biophys Res Commun. (1999) 257:79-83. doi: 10.1006/bbrc.1999.0255

41. Oshima K, Nampei A, Matsuda M, Iwaki M, Fukuhara A, Hashimoto $\mathrm{J}$, et al. Adiponectin increases bone mass by suppressing osteoclast and activating osteoblast. Biochem Biophys Res Commun. (2005) 33:520-6. doi: 10.1016/j.bbrc.2005.03.210

42. Sierra-Honigmann MR, Nath AK, Murakami C, Garcia-Cardena G, Papapetropoulos A, Sessa WC, et al. Biological action of leptin as an angiogenic factor. Science. (1998) 281:1683-6. doi: $10.1126 /$ science. 281.5383 .1683

43. Maeda N, Shimomura I, Kishida K, Nishizawa H, Matsuda M, Nagaretani H, et al. Diet-induced insulin resistance in mice lacking adiponectin/ACRP30. Nat Med. (2002) 8:731-7. doi: 10.1038/nm724

44. Weiler HA, Janzen L, Green K, Grabowski J, Seshia MM, Yuen KC. Percent body fat and bone mass in healthy Canadian females 10 to 19 years of age. Bone. (2000) 27:203-7. doi: 10.1016/S8756-3282(00)00314-8

45. Hamrick MW, Pennington C, Newton D, Xie D, Isales C. Leptin deficiency produces contrasting phenotypes in bones of the limb and spine. Bone. (2004) 34:376-83. doi: 10.1016/j.bone.2003.11.020

46. Cao JJ, Gregoire BR, Gao H. High-fat diet decreases cancellous bone mass but has no effect on cortical bone mass in the tibia in mice. Bone. (2009) 44:1097-104. doi: 10.1016/j.bone.2009.02.017

47. Cao JJ, Sun L, Gao H. Diet-induced obesity alters bone remodeling leading to decreased femoral trabecular bone mass in mice. AnnN Y Acad Sci. (2010) 1192:292-7. doi: 10.1111/j.1749-6632.2009.05252.x

48. Kyung TW, Lee JE, Phan TV, Yu R, Choi HS. Osteoclastogenesis by bone marrow-derived macrophages is enhanced in obese mice. J Nutr. (2009) 139:502-6. doi: 10.3945/jn.108.100032

49. Halade GV, Rahman MM, Williams PJ, Fernandes G. High fat diet-induced animal model of age-associated obesity and osteoporosis. J Nutr Biochem. (2010) 11:62-9. doi: 10.1016/j.jnutbio.2009.10.002

50. Nelson SE, Frantz JA, Ziegler EE. Absorption of fat and calcium by infants fed a milk-based formula containing palm olein. J Am Coll Nutr. (1998) 17:327-32. doi: 10.1080/07315724.1998.10718770

51. Carnielli VP, Luijendijk IH, Van Goudoever JB, Sulkers EJ, Boerlage $A A$, Degenhart $H J$, et al. Structural position and amount of palmitic acid in infant formulas: effects on fat, fatty acid, and mineral balance. J Pediatr Gastroenterol Nutr. (1996) 23:553-60. doi: 10.1097/00005176-199612000-00007 
52. Lucas A, Quinlan P, Abrams S, Ryan S, Meah S, Lucas PJ. Randomised controlled trial of a synthetic triglyceride milk formula for preterm infants. Arch Dis Child Fetal Neonatal Ed. (1997) 77:F178-184. doi: 10.1136/fn.77.3.F178

53. Zhang Y, Proenca R, Maffei M, Barone M, Leopold L, Friedman JM. Positional cloning of the mouse obese gene and its human homologue. Nature. (1994) 372:425-32. doi: 10.1038/372425a0

54. Mohamed-Ali V, Pinkney JH, Coppack SW. Adipose tissue as an endocrine and paracrine organ. Int J Obes Relat Metab Disord. (1998) 22:1145-58. doi: 10.1038/sj.ijo.0800770

55. Hotamisligil GS. Inflammation and metabolic disorders. Nature. (2006) 444:860-7. doi: 10.1038/nature05485

56. Xu H, Barnes GT, Yang Q, Tan G, Yang D, Chou CJ, et al. Chrohnic inflammation in fat plays a crucial role in the development of obesity-related insulin resistance. J Clin Invest. (2003) 112:1821-30. doi: 10.1172/JCI19451

57. Weisberg SP, McCann D, Desai M, Rosenbaum M, Leibel RL, Ferrante AW. Obesity is associated with macrophage accumulation in adipose tissue. J Clin Invest. (2003) 112:1796-808. doi: 10.1172/JCI200319246

58. Hotamisligil GS, Arner P, Caro JF, Atkinson RL, Spiegelman BM. Increased adipose tissue expression of tumor necrosis factor-alpha in human obesity and insulin resistance. J Clin Invest. (1995) 95:2409-15. doi: 10.1172/JCI117936

59. Wellen KE, Hotamisligil GS. Inflammation, stress, and diabetes. J Clin Invest. (2005) 115:1111-9. doi: 10.1172/JCI200525102

60. Pradhan AD, Manson JE, Rifai N, Buring JE, Ridker PM. C-reactive protein, interleukin 6, and risk of developing type 2 diabetes mellitus. J Am Med Assoc. (2001) 286:327-34. doi: 10.1001/jama.286.3.327

61. Anandacoomarasamy A, Caterson I, Sambrook P, Fransen M, March L. The impact of obesity on the musculoskeletal system. Int J Obes. (2008) 32:211-22. doi: 10.1038/sj.ijo.0803715

62. Skerry TM. The effects of the inflammatory response on bone growth. Eur J Clin Nutr. (1994) 48:S190-197.

63. Roy B, Curtis ME, Fears LS, Nahashon SN, Fentress HM. Molecular mechanisms of obesity-induced osteoporosis and muscle atrophy. Front Physiol. (2016) 7:439. doi: 10.3389/fphys.2016.00439

64. Brunetti G, Papadia F, Tummolo A, Fischetto R, Nicastro F, Piacente L, et al. Impaired bone remodeling in children with osteogenesis imperfecta treated and untreated with bisphosphonates: the role of DKK1, RANKL, and TNF- $\alpha$. Osteoporos Int. (2016) 27:2355-65. doi: 10.1007/s00198-016-3501-2

65. Ventura A, Brunetti G, Colucci S, Oranger A, Ladisa F, Cavallo L, et al. Glucocorticoid-induced osteoporosis in children with 21-hydroxylase deficiency. Biomed Res Int. (2013) 2013:250462. doi: 10.1155/2013/ 250462

66. Brunetti, G., Marzano, F., Colucci, S., Ventura, A., Cavallo, L., Grano, M., et al. (2012). Genotype-phenotype correlation in juvenile Paget disease: role of molecular alterations of the TNFRSF11B gene. Endocrine 42:266-271. doi: 10.1007/s12020-012-9705-0

67. Matsushima K, Larsen CG, DuBois GC, Oppenheim JJ. Purification and characterization of a novel monocyte chemotactic and activating factor produced by a human myelomonocytic cell line. J Exp Med. (1989) 169:1485-90

68. Cushing SD, Berliner JA, Valente AJ, Territo MC, Navab M, Parhami F, et al. Minimally modified low density lipoprotein induces monocyte chemotactic protein 1 in human endothelial cells and smooth muscle cells. Proc Natl Acad Sci USA. (1990) 87:5134-8.

69. Sica A, Wang JM, Colotta F, Dejana E, Mantovani A, Oppenheim JJ, et al. Monocyte chemotactic and activating factor gene expression induced in endothelial cells by IL-1 and tumor necrosis factor. J Immunol. (1990) 144:3034-8.

70. Rollins BJ, Pober JS. Interleukin-4 induces the synthesis and secretion of MCP-1/JE by human endothelial cells. Am J Pathol. (1991) 138:1315-9.

71. Colotta F, Sciacca FL, Sironi M, Luini W, Rabiet MJ, Mantovani A. Expression of monocyte chemotactic protein-1 by monocytes and endothelial cells exposed to thrombin. Am J Pathol. (1994) 144:975-85.

72. Shyy YJ, Hsieh HJ, Usami S, Chien S. Fluid shear stress induces a biphasic response of human monocyte chemotactic protein 1 gene expression in vascular endothelium. Proc Natl Acad Sci USA. (1994) 91:4678-82. doi: $10.1073 /$ pnas.91.11.4678
73. Van Damme J, Proost JP, Put W, Arens S, Lenaerts JP, Conings R, et al. Induction of monocyte chemotactic proteins MCP-1 and MCP-2 in human fibroblasts and leukocytes by cytokines and cytokine inducers. Chemical synthesis of MCP-2 and development of a specific RIA. J. Immunol. (1994) 152:5495-5502.

74. Struyf S, Van Coillie E, Paemen L, Put W, Lenaerts JP, Proost P, et al. Synergistic induction of monocyte chemotactic protein-1 and-2 by interleukin- $1 \beta$ and interferons in fibroblasts and epithelial cells. J Leukoc Biol. (1998) 63:364-72. doi: 10.1002/jlb.63.3.364

75. Yoshimura T, Robinson EA, Tanaka S, Appella E, Leonard EJ. Purification and amino acid analysis of two human monocyte chemoattractants produced by phytohemagglutinin-stimulated human blood mononuclear leukocytes. $J$ Immunol. (1989) 142:1956-62.

76. Chang HC, Hsu F, Freeman GJ, Griffn JD, Reinherz EL. Cloning and expression of a g-interferon-inducible gene in monocytes: a new member of a cytokine gene family. Int Immunol. (1989) 1:388-97. doi: 10.1093/intimm/1.4.388

77. McKee CM, Penno MB, Cowman M, Burdick MD, Strieter RM, Bao C, et al. Hyaluronan fragments induce chemokine gene expression in alveolar macrophages. The role of HA size and CD44. J. Clin. Invest. (1996) 98:24032413. doi: 10.1172/JCI119054

78. Yoshimura T, Yuhki N, Moore SK, Appella E, Lerman MI, Leonard EJ. Human monocyte chemoattractant protein-1 (MCP-1). Full-length cDNA cloning, expression in mitogenstimulated blood mononuclear leukocytes, and sequence similarity to mouse competence gene JE FEBS Lett. (1989) 244:487-93. doi: 10.1016/0014-5793(89)80590-3

79. Colotta F, Borré A, Wang JM, Tattanelli M, Maddalena F, Polentarutti N, et al Expression of a monocyte chemotactic cytokine by human mononuclear phagocytes. J. Immunol. (1992) 148:760-765.

80. Seitz M, Loetscher P, Dewald B, Towbin H, Gallati H, Baggiolini M. Interleukin-10 differentially regulates cytokine inhibitor and chemokine release from blood mononuclear cells and fibroblasts. Eur J Immunol. (1995) 25:1129-32. doi: 10.1002/eji.1830250443

81. Badolato R, Ponzi AN, Millesimo M, Notarangelo LD, Musso T. Interleukin15 (IL-15) induces IL-8 and monocyte chemotactic protein 1 production in human monocytes. Blood. (1997) 90:2804-9.

82. Biswas P, Delfanti F, Bernasconi S, Mengozzi M, Cota M, Polentarutti N, et al. Interleukin-6 induces monocyte chemotactic protein-1 in peripheral blood mononuclear cells and in the U937 cell line. Blood. (1998) 91:258-65.

83. Baghestanian M, Hofbauer R, Kiener HP, Bankl HC, Wimazal F, Willheim $\mathrm{M}$, et al. The c-kit ligand stem cell factor and anti-IgE promote expression of monocyte chemoattractant protein-1 in human lung mast cells. Blood. (1997) 90:4438-49.

84. Standiford TJ, Kunkel SL, Phan SH, Rollins BJ, Strieter RM. Alveolar macrophage-derived cytokines induce monocyte chemoattractant protein-1 expression from human pulmonary type II-like epithelial cells. J Biol Chem. (1991) 266:9912-8

85. Barker JNWN, Jones ML, Swenson CL, Sarma V, Mitra RS, Ward PA, et al. Monocyte chemotaxis and activating factor production by keratinocytes in response to IFN- $\gamma$. J. Immunol. (1991) 146:1192-7

86. Zachariae COC, Thestrup-Pedersen K, Matsushima K. Expression and secretion of leukocyte chemotactic cytokines by normal human melanocytes and melanoma cells. J Invest Dermatol. (1991) 97:593-9. doi: 10.1111/1523-1747.ep12481934

87. Wang JM, Sica A, Peri G, Walter S, Padura IM, Libby $P$, et al. Expression of monocyte chemotactic protein and interleukin- 8 by cytokineactivated human vascular smooth muscle cells. Arterioscler Thromb. (1991) 11:1166-74.

88. Torzewski J, Oldroyd R, Lachmann P, Fitzsimmons C, Proudfoot D, Bowyer D. Complement-induced release of monocyte chemotactic protein1 from human smooth muscle cells. A possible initiating event in atherosclerotic lesion formation Arterioscler Thromb Vasc Biol. (1996) 16:673-7. doi: 10.1161/01.ATV.16.5.673

89. Jonjic N, Peri G, Bernasconi S, Sciacca FL, Colotta F, Pelicci P, et al. Expression of adhesion molecules and chemotactic cytokines in cultured human mesothelial cells. J Exp Med. (1992) 176:1165-74. doi: 10.1084/jem.176.4.1165 
90. Van Damme J, Proost P, Lenaerts JP, Opdenakker G. Structural and functional identification of two human, tumor-derived monocyte chemotactic proteins (MCP-2 and MCP-3) belonging to the chemokine family. J Exp Med. (1992) 176:59-65. doi: 10.1084/jem.176.1.59

91. Garcia-Zepeda EA, Rothenberg ME, Ownbey RT, Celestin J, Leder P, Luster AD. Human eotaxin is a specific chemoattractant for eosinophil cells and provides a new mechanism to explain tissue eosinophilia. Nat Med. (1996) 2:449-256.

92. Brown Z, Strieter RM, Neild GH, Thompson RC, Kunkel SL, Westwick J. IL-1 receptor antagonist inhibits monocyte chemotactic peptide 1 generation by human mesangial cells. Kidney Int. (1992) 42:95-101. doi: 10.1038/ki.1992.266

93. Rovin BH, Yoshimura T, Tan L. Cytokine-induced production of monocyte chemoattractant protein-1 by cultured human mesangial cells. J Immunol. (1992) 148:2148-53.

94. Grandaliano G, Valente AJ, Abboud HE. A novel biologic activity of thrombin: stimulation of monocyte chemotactic protein production. J Exp Med. (1994) 179:1737-41. doi: 10.1084/jem.179.5.1737

95. Grandaliano G, Valente AJ, Rozek MM. Gamma interferon stimulates monocyte chemotactic protein (MCP-1) in human mesangial cells. J Lab Clin Med. (1994) 123:282-9.

96. Schwarz M, Radeke HH, Resch K, Uciechowski P. Lymphocyte-derived cytokines induce sequential expression of monocyte- and T cell-specific chemokines in human mesangial cells. Kidney Int. (1997) 52:1521-31. doi: 10.1038/ki.1997.482

97. Villiger PM, Terkeltaub R, Lotz M. Monocyte chemoattractant protein1 (MCP-1) expression in human articular cartilage. Induction by peptide regulatory factors and differential effects of dexamethasone and retinoic acid. J Clin Invest. (1992) 90:488-96. doi: 10.1172/JCI115885

98. Barna BP, Pettay J, Barnett GH, Zhou P, Iwasaki K, Estes ML. Regulation of monocyte chemoattractant protein-1 expression in adult human nonneoplastic astrocytes is sensitive to tumor necrosis factor (TNF) or antibody to the 55-kDa TNF receptor. J Neuroimmunol. (1994) 50:101-7. doi: 10.1016/0165-5728(94)90220-8

99. Peterson PK, Hu S, Salak-Johnson J, Molitor TW, Chao CC. Differential production of and migratory response to $\mathrm{b}$ chemokines by human microglia and astrocytes. J Infect Dis. (1997) 175:478-81. doi: 10.1093/infdis/175.2.478

100. Opdenakker G, Van Damme J. (1999) Chemokines and Cancer. Rollins, B.J, editors. Totowa, NJ: Humana Press,

101. Graves DT, Jiang YL, Williamson MJ, Valente AJ. Identification of monocyte chemotactic activity produced by malignant cells. Science. (1989) 245:14903. doi: 10.1126/science. 2781291

102. Bottazzi B, Colotta F, Sica A, Nobili N, Mantovani A. A chemoattractant expressed in human sarcoma cells (tumor-derived chemotactic factor, TDCF) is identical to monocyte chemoattractant protein- $1 /$ monocyte chemotactic and activating factor (MCP-1/MCAF). Int J Cancer. (1990) 45:795-7. doi: 10.1002/ijc.2910450436

103. Takeya M, Yoshimura T, Leonard EJ, Kato T, Okabe H, Takahashi K. Production of monocyte chemoattractant protein-1 by malignant ${ }^{\circledR}$ brous histiocytoma: relation to the origin of histiocyte-like cells. Exp Mol Pathol. (1991) 54:61-71. doi: 10.1016/0014-4800(91)90044-X

104. Mantovani A, Bottazzi B, Colotta F, Sozzani S, Ruco L. The origin and function of tumor-associated macrophages. Immunol Today. (1992) 13:26570. doi: 10.1016/0167-5699(92)90008-U

105. Brach MA, Gruss H-J, Riedel D, Asano Y, De Vos S, Herrmann F. Effect of anti-inflammatory agents on synthesis of MCP-1/JE transcripts by human blood monocytes. Mol Pharmacol. (1992) 42:63-8.

106. Lukacs NW, Kunkel SL, Burdick MD, Strieter RM. The production of chemotactic cytokines in an allogeneic response. The role of intercellular adhesion molecule-1 and lymphocyte function-associated antigen-3. Am. J. Pathol. (1993) 143:1179-88.

107. Liebler JM, Kunkel SL, Burdick MD, Standiford TJ, Rolfe MW, Strieter RM. Production of IL- 8 and monocyte chemotactic peptide- 1 by peripheral blood monocytes. Disparate responses to phytohemagglutinin and lipopolysaccharide. J Immunol. (1994) 152:241-9.

108. Zeiher AM, Fisslthaler B, Schray-Utz B, Busse R. Nitric oxide modulates the expression of monocyte chemoattractant protein 1 in cultured human endothelial cells. Circ Res. (1995) 76:980-6.
109. Miyamasu M, Misaki Y, Izumi S, Takaishi T, Morita Y, Nakamura $\mathrm{H}$, et al. Glucocorticoids inhibit chemokine generation by human eosinophils. J Allergy Clin Immunol. (1998) 101:75-83. doi: 10.1016/S0091-6749(98)70196-4

110. Van Coillie E, Proost P, Van Aelst I, Struyf S, Polfliet M, De Meester I, et al. Functional comparison of two human monocyte chemotactic protein-2 isoforms, role of the aminoterminal pyroglutamic acid and processing by CD26/dipeptidyl peptidase IV. Biochemistry. (1998) 37:1267280. doi: 10.1021/bi980497d

111. Masure S, Paemen L, Proost P, Van Damme J, Opdenakker G. Expression of a human mutant monocyte chemotactic protein 3 in Pichia pastoris and characterization as an MCP-3 receptor antagonist. J Interferon Cytokine Res. (1995) 15:955-63. doi: 10.1089/jir.1995.15.955

112. Lodi PJ, Garrett DS, Kuszewski J, Tsang MLS, Weatherbee JA, Leonard WJ, et al. High-resolution solution structure of the $b$ chemokine hMIP-1b by multidimensional NMR. Science. (1994) 263:1762-7. doi: 10.1126/science.8134838

113. Paolini JF, Willard D, Consler T, Luther M, Krangel MS. The chemokines IL-8, monocyte chemoattractant protein-1, and I-309 are monomers at physiologically relevant concentrations. J Immunol. (1994) 153:2704-17.

114. Handel TM, Domaille PJ. Heteronuclear $(1 \mathrm{H}, 13 \mathrm{C}, 15 \mathrm{~N})$ NMR assignments and solution structure of the monocyte chemoattractant protein-1 (MCP-1) dimer. Biochemistry. (1996) 35:6569-84. doi: 10.1021/bi9602270

115. Lubkowski J, Bujacz G, Boque L, Domaille PJ, Handel TM, Wlodawer A. The structure of MCP-1 in two crystal forms provides a rare example of variable quaternary interactions. Nat Struct Biol. (1997). 4:649.

116. Cochran BH, Reffel AC, Stiles CD. Molecular cloning of gene sequences regulated by platelet-derived growth factor. Cell. (1983) 33:939-47. doi: 10.1016/0092-8674(83)90037-5

117. Kim MS, Day CJ, Selinger CI, Magno CL, Stephens SR, Morrison NA. MCP1 -induced human osteoclast-like cells are tartrate-resistant acid phosphatase, NFATc1, and calcitonin receptor-positive but require receptor activator of NFkappaB ligand for bone resorption. J Biol Chem. (2006) 281:1274-85. doi: 10.1074/jbc.M510156200

118. Wiley SR, Schooley K, Smolak PJ, Din WS, Huang CP, Nicholl $\mathrm{JK}$, et al. Identification and characterization of a new member of the TNF family that induces apoptosis. Immunity. (1995) 3:673-82. doi: 10.1016/1074-7613(95)90057-8

119. Azijli K, Weyhenmeyer B, Peters GJ, de Jong S, Kruyt FA. Noncanonical kinase signaling by the death ligand TRAIL in cancer cells: discord in the death receptor family. Cell Death Differ. (2013) 20:858-68. doi: $10.1038 / \mathrm{cdd} .2013 .28$

120. Gonzalvez F, Ashkenazi A. New insights into apoptosis signaling by Apo2L/TRAIL. Oncogene. (2010) 29:4752-65. doi: 10.1038/onc.2010.221

121. Vigneri P, Frasca F, Sciacca L, Pandini G, Vigneri R. Diabetes and cancer. Endocr Relat Cancer. (2009) 16:1103-23. doi: 10.1677/ERC-09-0087

122. Roux S, Lambert-Comeau P, Saint-Pierre C, Lépine M, Sawan B, Parent JL. Death receptors, Fas and TRAIL receptors, are involved in human osteoclast apoptosis. Biochem Biophys Res Commun. (2005) 333:42-50. doi: 10.1016/j.bbrc.2005.05.092

123. Colucci S, Brunetti G, Cantatore FP, Oranger A, Mori G, Pignataro P, et al. The death receptor DR5 is involved in TRAIL-mediated human osteoclast apoptosis. Apoptosis. (2007) 12:1623-32.

124. Brunetti G, Di Benedetto A, Posa F, Colaianni G, Faienza MF, Ballini A, et al. High expression of TRAIL by osteoblastic differentiated dental pulp stem cells affects myeloma cell viability. Oncol Rep. (2018d) 39:2031-9. doi: $10.3892 /$ or. 2018.6272

125. Keuper M, Wernstedt Asterholm I, Scherer PE, Westhoff MA, Möller P, Debatin KM, et al. TRAIL (TNF-related apoptosis-inducing ligand) regulates adipocyte metabolism by caspase-mediated cleavage of PPARgamma. Cell Death Dis. (2013) 4:e474. doi: 10.1038/cddis.2012.212

126. Galeone A, Zoller V, El Hay MA, Debatin KM, Wabitsch M, FischerPosovszky P. Aortic valvular interstitial cells apoptosis and calcification are mediated by TNF-related apoptosis-inducing ligand. Int J Cardiol. (2013) 169:296-304. doi: 10.1016/j.ijcard.2013.09.012

127. Secchiero P, Gonelli A, Carnevale E, Milani D, Pandolfi A, Zella D, et al. TRAIL promotes the survival and proliferation of primary human vascular 
endothelial cells by activating the Akt and ERK pathways. Circulation. (2003) 107:2250-6. doi: 10.1161/01.CIR.0000062702.60708.C4

128. Evdokiou A, Bouralexis S, Atkins GJ, Chai F, Hay S, et al. Chemotherapeutic agents sensitize osteogenic sarcoma cells, but not normal human bone cells, to Apo2L/TRAIL-induced apoptosis. Int J Cancer. (2002) 99:491504.doi: 10.1002/ijc.10376

129. Mori G, Brunetti G, Colucci S, Ciccolella F, Coricciati M, Pignataro P, et al. Alteration of activity and survival of osteoblasts obtained from human periodontitis patients: role of TRAIL. J Biol Regul Homeost Agents. (2007) 21:105-14.

130. Mori G, Brunetti G, Colucci S, Oranger A, Ciccolella F, Sardone F, et al. Osteoblast apoptosis in periodontal disease: role of TNF-related apoptosis-inducing ligand. Int J Immunopathol Pharmacol. (2009) 22:95103. doi: $10.1177 / 039463200902200111$

131. Brunetti G, Oranger A, Carbone C, Mori G, Sardone FR, Mori C, et al. Osteoblasts display different responsiveness to TRAIL-induced apoptosis during their differentiation process. Cell Biochem Biophys. (2013) 67:112736. doi: 10.1007/s12013-013-9616-6

132. Brunetti G, Oranger A, Mori G, Sardone F, Pignataro P, Coricciati M, et al. TRAIL effect on osteoclast formation in physiological and pathological conditions. Front Biosci. (2011) 3:1154-61.

133. Zauli G, Rimondi E, Nicolin V, Melloni E, Celeghini C, Secchiero P. TNF-related apoptosis-inducing ligand (TRAIL) blocks osteoclastic differentiation induced by RANKL plus M-CSF. Blood. (2004) 104:2044-50. doi: 10.1182/blood-2004-03-1196

134. Zoller V, Funcke JB, Roos J, Dahlhaus M, Abd El Hay M, Holzmann $\mathrm{K}$, et al. Trail (TNF-related apoptosis-inducing ligand) induces an inflammatory response in human adipocytes. Sci Rep. (2017) 7:5691. doi: 10.1038/s41598-017-05932-7

135. Funcke JB, Zoller V, El Hay MA, Debatin KM, Wabitsch M, FischerPosovszky P. TNF-related apoptosis-inducing ligand promotes human preadipocyte proliferation via ERK1/2 activation. FASEB J. (2015) 29:306575. doi: 10.1096/fj.14-267278

136. van Kruijsdijk RC, van der Wall E, Visseren FL. Obesity and cancer: the role of dysfunctional adipose tissue. Cancer Epidemiol Biomarkers Prev. (2009) 18:2569-78. doi: 10.1158/1055-9965.EPI-09-0372

137. Choi JW, Song JS, Soo HP. Associations of serum TRAIL concentrations, anthropometric variables, and serum lipid parameters in healthy adults. Ann. Clin. Lab. Sci. (2004) 34:400-404.

138. Ashley DT, O'Sullivan EP, Davenport C, Devlin N, Crowley RK, McCaffrey $\mathrm{N}$, et al. Similar to adiponectin, serum levels of osteoprotegerin are associated with obesity in healthy subjects. Metab Clin Exp. (2011) 60:994-1000. doi: 10.1016/j.metabol.2010.10.001

139. Biolo G, Secchiero P, De Giorgi S, Tisato V, Zauli G. The energy balance positively regulates the levels of circulating TNF-related apoptosis inducing ligand in humans. Clin Nutr. (2012) 105:12-20. doi: 10.1016/j.clnu.2012.04.016

140. Brombo G, Volpato S, Secchiero P, Passaro A, Bosi C, Zuliani G, et al. Association of soluble tumor necrosis factor related apoptosis-inducing ligand (TRAIL) with central adiposity and low-density lipoprotein cholesterol. PLoS ONE. (2013) 8:e58225. doi: 10.1371/journal.pone. 0058225

141. Mori K, Ikari Y, Jono S, Shioi A, Ishimura E, Emoto M, et al. Association of serum TRAIL level with coronary artery disease. Thromb Res. (2010) 125:322-5. doi: 10.1016/j.thromres.2009.11.024

142. Davenport C, Kenny H, Ashley DT, O'Sullivan EP, Smith D, O'Gorman DJ. The effect of exercise on osteoprotegerin and TNF-related apoptosisinducing ligand in obese patients. Eur J Clin Invest. (2012) 42:1173-9. doi: $10.1111 /$ j.1365-2362.2012.02703.x

143. Bernardi S, Zauli G, Tikellis C, Candido R, Fabris B, Secchiero $\mathrm{P}$, et al. TNF-related apoptosis-inducing ligand significantly attenuates metabolic abnormalities in high-fat-fed mice reducing adiposity and systemic inflammation. Clin Sci. (2012) 123:547-55. doi: 10.1042/CS201 20176

144. Di Bartolo BA, Chan J, Bennett MR, Cartland S, Bao S, Tuch BE, et al. TNF-related apoptosis-inducing ligand (TRAIL) protects against diabetes and atherosclerosis in Apoe/ mice. Diabetologia. (2011) 54:3157-67. doi: 10.1007/s00125-011-2308-0
145. Šedý J, Bekiaris V, Ware CF. Tumor necrosis factor superfamily in innate immunity and inflammation. Cold Spring Harb. Perspect. Biol. (2014) 7:a016279. doi: 10.1101/cshperspect.a016279

146. Gommerman JL, Browning JL, Ware CF. The Lymphotoxin Network: orchestrating a type I interferon response to optimize adaptive immunity. Cytokine Growth Factor Rev. (2014) 25:139-45. doi: 10.1016/j.cytogfr.2014.02.002

147. Steinberg MW, Cheung TC, Ware CF. The signaling networks of the herpesvirus entry mediator (TNFRSF14) in immune regulation. Immunol Rev. (2011) 244:169-87. doi: 10.1111/j.1600-065X.2011. 01064.x

148. Ware CF, Sedý JR. TNF Superfamily Networks: bidirectional and interference pathways of the herpesvirus entry mediator (TNFSF14). Curr. Opin. Immunol. (2011) 23:627-631. doi: 10.1016/j.coi.2011.08.008

149. Mauri DN, Ebner R, Montgomery RI, Kochel KD, Cheung TC, Yu GL, et al. LIGHT, a new member of the TNF superfamily, and lymphotoxin $\alpha$ are ligands for herpesvirus entry mediator. Immunity. (1998) 8:21-30. doi: 10.1016/S1074-7613(00)80455-0

150. Tamada K, Shimozaki K, Chapoval AI, Zhai Y, Su J, Chen SF, et al. LIGHT, a TNF-like molecule, costimulates $\mathrm{T}$ cell proliferation and is required for dendritic cell-mediated allogeneic T cell response. J Immunol. (2000) 164:4105-10. doi: 10.4049/jimmunol.164.8.4105

151. Holmes TD, Wilson EB, Black EV, Benest AV, Vaz C, Tan B, et al. Licensed human natural killer cells aid dendritic cell maturation via TNFSF14/LIGHT. Proc Natl Acad Sci USA. (2014) 111:E5688-5696. doi: 10.1073/pnas.1411072112

152. Harrop JA, Reddy M, Dede K, Brigham-Burke M, Lyn S, Tan KB, et al. Antibodies to TR2 (herpesvirus entry mediator), a new member of the TNF receptor superfamily, block T cell proliferation, expression of activation markers, and production of cytokines. J Immunol. (1998) 161:1786-94.

153. Kwon BS, Tan KB, Ni J, Oh KO, Lee ZH, Kim KK, et al. A newly identified member of the tumor necrosis factor receptor superfamily with a wide tissue distribution and involvement in lymphocyte activation. J Biol Chem. (1997) 272:14272-6. doi: 10.1074/jbc.272.22.14272

154. Tamada K, Shimozaki K, Chapoval AI, Zhu G, Sica G, Flies D, et al. Modulation of T-cell-mediated immunity in tumor and graft-versus-host disease models through the LIGHT co-stimulatory pathway. Nat Med. (2000) 6:283-9. doi: 10.1038/73136

155. Wang J, Lo JC, Foster A, Yu P, Chen HM, Wang Y, et al. The regulation of T cell homeostasis and autoimmunity by T cell-derived LIGHT. J Clin Invest. (2001) 108:1771-80. doi: 10.1172/JCI13827

156. Harrop JA, McDonnell PC, Brigham-Burke M, Lyn SD, Minton J, Tan $\mathrm{KB}$, et al. Herpesvirus entry mediator ligand (HVEM-L), a novel ligand for HVEM/TR2, stimulates proliferation of T cells and inhibits HT29 cell growth. J Biol Chem. (1998) 273:27548-56. doi: 10.1074/jbc.273.42. 27548

157. Tamada K, Ni J, Zhu G, Fiscella M, Teng B, van Deursen JM, et al. Cutting edge: selective impairment of CD8 $+\mathrm{T}$ cell function in mice lacking the TNF superfamily member LIGHT. J Immunol. (2002) 168:4832-5. doi: 10.4049/jimmunol.168.10.4832

158. Liu J, Schmidt CS, Zhao F, Okragly AJ, Glasebrook A, Fox N, et al. LIGHTdeficiency impairs CD8 $+\mathrm{T}$ cell expansion, but not effector function. Int Immunol. (2003) 15:861-70.

159. Brunetti G, Faienza MF, Colaianni G, Gigante I, Oranger A, Pignataro P, et al. Impairment of Bone Remodeling in LIGHT/TNFSF14-Deficient Mice. J Bone Miner Res. (2018) 33:704-19. doi: 10.1002/jbmr.3345

160. Brunetti G, Rizzi R, Oranger A, Gigante I, Mori G, Taurino G, et al. LIGHT/TNFSF14 increases osteoclastogenesis and decreases osteoblastogenesis in multiple myeloma-bone disease. Oncotarget. (2014) 5:12950-67. doi: 10.18632/oncotarget.2633

161. Brunetti G, Rizzi R, Storlino G, Bortolotti S, Colaianni G, Sanesi L, et al. LIGHT/TNFSF14 as a new biomarker of bone disease in multiple myeloma patients experiencing therapeutic regimens. Front Immunol. (2018) 9:2459. doi: 10.3389/fimmu.2018.02459

162. Brunetti G, Tummolo A, D’Amato G, Gaeta A, Ortolani F, Piacente L, et al. Mechanisms of enhanced osteoclastogenesis in alkaptonuria. Am J Pathol. (2018) 188:1059-68. doi: 10.1016/j.ajpath.2017.12.008 
163. Cafiero C, Gigante M, Brunetti G, Simone S, Chaoul N, Oranger A, et al. Inflammation induces osteoclast differentiation from peripheral mononuclear cells in chronic kidney disease patients: crosstalk between the immune and bone systems. Nephrol Dial Transplant. (2018) 33:65-75. doi: $10.1093 / \mathrm{ndt} / \mathrm{gf} \times 222$

164. Kim HM, Jeong CS, Choi HS, Kawada T, Yu R. LIGHT/TNFSF14 enhances adipose tissue inflammatory responses through its interaction with HVEM. FEBS Lett. (2011) 585:579-84. doi: 10.1016/j.febslet.2011.01.011

165. Choi EK, Kim WK, Sul OJ, Park YK, Kim ES, Suh JH, et al. TNFRSF14 deficiency protects against ovariectomy-induced adipose tissue inflammation. J Endocrinol. (2013) 220:25-33. doi: 10.1530/JOE13-0341

166. Tiller G, Laumen H, Fischer-Posovszky P, Finck A, Skurk T, Keuper $\mathrm{M}$, et al. LIGHT (TNFSF14) inhibits adipose differentiation without affecting adipocyte metabolism. Int $J$ Obes. (2011) 35:208-16. doi: 10.1038/ijo.2010.126

167. Kou Y, Liu Q, Liu W, Sun H, Liang M, Kong F, et al. LIGHT/TNFSF14 signaling attenuates beige fat biogenesis. FASEB J. (2019) 33:1595-604. doi: $10.1096 /$ fj.201800792R

168. Dandona P, Ghanim H, Monte SV, Caruana JA, Green K, Abuaysheh S, et al. Increase in the mediators of asthma in obesity and obesity with type 2 diabetes: reduction with weight loss. Obesity. (2014) 22:356-62. doi: 10.1002/oby.20524

169. Brunetti G, Piacente L, Ventura A, Aceto G, Colucci S, Cavallo L, et al. Immune-fat-bone axis in obese children: the role of LIGHT. Hormon Res. Ped. (2016) 86:37. doi: 10.1097/MD.0000000000001303

170. Dovio A, Data V, Angeli A. Circulating osteoprotegerin and soluble RANKL: do they have a future in clinical practice? J Endocrinol Invest. (2005) 28:14-22.

171. Chang $\mathrm{YH}$, Lin KD, He SR, Hsieh MC, Hsiao JY, Shin SJ. Serum osteoprotegerin and tumor necrosis factor related apoptosis inducingligand (TRAIL) are elevated in type 2 diabetic patients with albuminuria and serum osteoprotegerin is independently associated with the severity of diabetic nephropathy. Metab Clin Exp. (2011) 60:1064-9. doi: 10.1016/j.metabol.2010.11.002

172. Yilmaz Y, Yonal O, Kurt R, Oral AY, Eren F, Ozdogan O, et al. Serum levels of osteoprotegerin in the spectrum of nonalcoholic fatty liver disease. Scand J Clin Lab Invest. (2010) 70:5416. doi: 10.3109/00365513.2010. 524933

173. Yang M, Xu D, Liu Y, Guo X, Li W, Guo C, et al. Combined serum biomarkers in non-invasive diagnosis of non-alcoholic steatohepatitis. PLoS ONE. (2015) 10:e0131664. doi: 10.1371/journal.pone.0131664

174. Ugur-Altun B, Altun A, Gerenli M, Tugrul A. The relationship between insulin resistance assessed by HOMA-IR and serum osteoprotegerin levels in obesity. Diabetes Res Clin Pract. (2005) 68:217-22. doi: 10.1016/j.diabres.2004.10.011

175. Holecki M, Reddy M, Dede K, Brigham-Burke M, Lyn S, Tan KB, et al. The influence of weight loss on serum osteoprotegerin concentration in obese perimenopausal women Obesity (Silver Spring). (2007) 15:1925-9. doi: 10.1038/oby.2007.229

176. Gannagé-Yared MH, Yaghi C, Habre B, Khalife S, Noun R, GermanosHaddad $\mathrm{M}$, et al. Osteoprotegerin in relation to body weight, lipid parameters insulin sensitivity, adipocytokines, and C-reactive protein in obese and non-obese young individuals: results from both cross-sectional and interventional study. Eur J Endocrinol. (2008) 158:353-9. doi: 10.1530/EJE-0 7-0797

177. Gannage-Yared MH, Fares F, Semaan M, Khalife S, Jambart S. Circulating osteoprotegerin is correlated with lipid profile, insulin sensitivity, adiponectin and sex steroids in an ageing male population. Clin Endocrinol. (2006) 64:652-8. doi: 10.1111/j.1365-2265.2006.02522.x

178. Suliburska J, Bogdanski P, Gajewska E, Kalmus G, Sobieska M, Samborski W. The association of insulin resistance with serum osteoprotegerin in obese adolescents. J Physiol Biochem. (2013) 69:847-53. doi: 10.1007/s13105-013-0261-8

179. Jorgensen GM, Vind B, Nybo M, Rasmussen LM, Hojlund K. Acute hyperinsulinemia decreases plasma osteoprotegerin with diminished effect in type 2 diabetes and obesity. Eur J Endocrinol. (2009) 161:95-101. doi: 10.1530/EJE-09-0141
180. Yaturu S, Rains J, Jain SK. Relationship of elevated osteoprotegerin with insulin resistance, CRP, and TNF-alpha levels in men with type 2 diabetes. Cytokine. (2008) 44:168-71. doi: 10.1016/j.cyto.2008.07.471

181. Niu Y, Zhang W, Yang Z, Li X, Fang W, Zhang H, et al. Plasma osteoprotegerin levels are inversely associated with nonalcoholic fatty liver disease in patients with type 2 diabetes: a case-control study in China. Metab Clin Exp. (2016) 65:475-81. doi: 10.1016/j.metabol.2015.12.005

182. Xu F, Du Y, Hang S, Chen A, Guo F, Xu T. Adipocytes regulate the bone marrow microenvironment in a mouse model of obesity. Mol Med Rep. (2013) 8:823-8. doi: 10.3892/mmr.2013.1572

183. Gaur U, Aggarwal BB. Regulation of proliferation, survival and apoptosis by members of the TNF superfamily. Biochem Pharmacol. (2003) 6:1403-8. doi: 10.1016/S0006-2952(03)00490-8

184. Baud V, Karin M. Signal transduction by tumor necrosis factor and its relatives. Trends Cell Biol. (2001) 11:372-7. doi: 10.1016/S0962-8924(01)02064-5

185. Fain JN, Bahouth SW, Madan AK. TNF $\alpha$ release by the nonfat cells of human adipose tissue. Int J Obes Relat Metab Disord. (2004) 28:616-22. doi: 10.1038/sj.ijo.0802594

186. Osta B, Benedetti G, Miossec P. Classical and paradoxical effects of TNF-a on bone homeostasis. Front. Immunol. (2014) 5:48. doi: 10.3389/fimmu.2014.00048

187. Xu H, Sethi JK, Hotamisligil GS. Transmembrane tumor necrosis factor (TNF) $\alpha$ inhibits adipocyte differentiation by selectively activating TNF receptor 1. J. Biol. Chem. (1999) 274:26287-95. doi: 10.1074/jbc.274.37.26287

188. Christodoulides C, Lagathu C, Sethi JK, Vidal-Puig A. Adipogenesis and WNT signalling. Trends Endocrinol Metab. (2009) 20:16-24. doi: 10.1016/j.tem.2008.09.002

189. Hu E, Kim JB, Sarraf P, Spiegelman BM. Inhibition of adipogenesis through MAP kinase-mediated phosphorylation of PPAR $\gamma$. Science. (1996) 274:2100 3. doi: 10.1126/science.274.5295.2100

190. Palacios-Ortega S, Varela-Guruceaga M, Algarabel M, Ignacio Milagro F, Alfredo Martinez J de Miguel C, et al. Effect of TNF- $\alpha$ on caveolin1 expression and insulin signaling during adipocyte differentiation and in mature adipocytes. Cell Physiol Biochem. (2015) 36:1499-516. doi: 10.1159/000430314

191. Uysal KT, Wiesbrock SM, Marino MW, Hotamisligil GS. Protection from obesity-induced insulin resistance in mice lacking TNF- $\alpha$ function. Nature. (1997) 389:610-4. doi: 10.1038/39335

192. Liu S, Yang Y, Wu J. TNF $\alpha$-induced up-regulation of miR155 inhibits adipogenesis by down-regulating early adipogenic transcription factors. Biochem Biophys Res Commun. (2011) 414:618-24. doi: 10.1016/j.bbrc.2011.09.131

193. Zhu Y, Zhang X, Ding X, Wang H, Chen X, Zhao H, et al. miR-27 inhibits adipocyte differentiation via suppressing CREB expression. Acta Biochim Biophys Sin. (2014) 46:590-6. doi: 10.1093/abbs/gmu036

194. Xie H, Lim B, Lodish HF. MicroRNAs induced during adipogenesis that accelerate fat cell development are downregulated in obesity. Diabetes. (2009) 58:1050-7. doi: 10.2337/db08-1299

195. Moelants EA, Mortier A, Van Damme J, Proost P. Regulation of TNF- $\alpha$ with a focus on rheumatoid arthritis. Immunol Cell Biol. (2013) 91:393-401. doi: $10.1038 /$ icb.2013.15

196. Lam J, Takeshita S, Barker JE, Kanagawa O, Ross FP, Teitelbaum SL. TNF-alpha induces osteoclastogenesis by direct stimulation of macrophages exposed to permissive levels of RANK ligand. J Clin Invest. (2000) 106:14818. doi: $10.1172 / \mathrm{JCI} 11176$

Conflict of Interest Statement: The authors declare that the research was conducted in the absence of any commercial or financial relationships that could be construed as a potential conflict of interest.

Copyright (C) 2019 Faienza, D’Amato, Chiarito, Colaianni, Colucci, Grano, Corbo and Brunetti. This is an open-access article distributed under the terms of the Creative Commons Attribution License (CC BY). The use, distribution or reproduction in other forums is permitted, provided the original author(s) and the copyright owner(s) are credited and that the original publication in this journal is cited, in accordance with accepted academic practice. No use, distribution or reproduction is permitted which does not comply with these terms. 